\title{
THE MAKING OF THE MEDIEVAL MALAY HERO HANG TUAH: STORIES BEHIND THE EPIC SCENE
}

\author{
Noriah Taslim \\ tnoriah@gmail.com
}

Faculty of Arts and Social Sciences

Universiti Brunei Darussalam

\begin{abstract}
The essay attempts to look at the scene behind the making of a hero in Malay medieval society. Such attempt is vital in order to understand not only the rise of a legendary hero, Hang Tuah, from his ordinary status in Sejarah Melayu (The Malay Annal) to his supra-human figure in the epic Hikayat Hang Tuah but also to gauge the social, political and psychological milieu behind the epic composition. The premise of the argument in this essay is that a hero is built and not born. Pushing it from there, the essay endeavours to prove the point by extensively reading on the milieu and time behind the emergence of Hikayat Hang Tuah. While exploring these, the essay also looks at the process of inventing the epic, which include identifying sources and materials borrowed, distorted, inverted and appropriated by the author to bring forth this traditional but unique literary creation.
\end{abstract}

Keywords: epic, hero, heroism, heroic deeds, heroic age, ethnocentrism

\section{INTRODUCTION}

The so-called "Malay hikayat literature" (encompassing all genres) had always had a bad name among Malayists in the past; myriad of comments coming from scholar or researchers stating that the Malay hikayats were just "an assemblage of tales and legends" or "a product of Malay fantasy" or perhaps merely "a confuse history without recourse to any real events 
in the past". While many considered them as "silly and boring texts"; and as works of literature, "these texts lack literary merits and their moral tone was bad". However, in our reappraisal of these hikayats, we believe that these views were much maligned by the so-called western-centric vision of other cultures (Malay culture included), based on a rather skewed model of literary evaluation. I do not however, plan to verify my points here, but suffice to say that, if we desire for a more balanced appraisal and appreciation of these hikayats, we need to reposition our reading strategy and to look for more accountable methods of evaluation. These will certainly involve first and foremost a shift in our reading orientation-from western centeredness to Malay centeredness. This essay is an attempt at that.

\section{THE EPIC HIKAYAT HANG TUAH: ITS GENRE, STRUCTURE AND NATURE}

This brings us to the topic at hand. We are dealing with one of the most well-known hikayats in the corpus of Malay medieval literature, viz. the Hikayat Hang Tuah (henceforth, HHT). HHT was indeed a confusing texts to the Malayists-it is a complexly hybrid narrative and its contents oscillating between fact and fantasy, legend and history. To add up to the confusion, HHT like most Malay medieval texts, exhibits structural features that defy straight forward attempt for it to be categorized into any specific genre. Thus, Winstedt (1961), a strong proponent of the evolutionary positivism (Maier, 1985) called it "a Malayo-Javanese romance" while others considered it as "an adventure romance" or at best "a Malay legendary romance" (Hooykaas, 1953); Teeuw later on (1964) coined the term "a Malay romance" to resolve the confusion and misunderstanding over the historical nature of the text (see T. Iskandar,1970; Parnickel, 1976).

We are here not to repudiate these rather arbitrary claims on $H H T,{ }^{1}$ but to point out the incorrectness of the arguments that were brought upon the text that subsequently led to the wrong conclusion as to the nature of its genre. As what we perceive thus far, these western scholars had not fully grasped the obvious structural features that point to the exact genre of this text. This is partly regarded due to the short-sightedness of these scholars in viewing an alien culture. They, like most orientalists in the colonial era were incapable of viewing other cultures without filtering any racial prejudices and stereotypes that stemmed from the 19th century western notions about themselves and others (see Edward Said, 1978). 
Within this ideological frame, Malay literature was perceived as a product of an inferior race (sometimes referred to as semi-civilized) and thus do not merit, so to speak, a more serious attention. To simplify the matters, $H H T$ then was likened to the "panji romance" or at best, it was just another "hikayat romance", of the same category as Hikayat Inderaputera. Though admittedly, HHT does share some common features of the hikayat romance, it also exhibits its own structural uniqueness, a complexity of theme and idiosyncrasy of character that detached it from its counterpart-the ordinary and typical hikayat romance.

Kassim Ahmad (1964) aptly pointed HHT to a specific genre. He called it a national epic-probably the most original Malay epic (and also Malay texts) and the only one in the history of medieval Malay literature; and not a modest one at that but a full scale epic both in style and narrative structures. $H H T$ is unquestionably an epic par excellance; indeed, to quote Valentijn's remark (in T. Iskandar, 1970) "a very rare gem" and "the best of Malay composition."

As an epic, $H H T$ is first and foremost a work of literature (as Teeuw, 1964 rightly pointed out). This notion would help to cancel out any attempt to read it as "history" or a historical work in the modern sense; and also help to point to the futility of finding correspondences between the texts and the real world. This is because literature does not mimic the real world in its literal sense but distorts and manipulates, deconstructs and recreates it, to bring forth another world, an allusion to and illusion of the real world. This however does not obliterate the fact that "history" is still present and traceable in literary text; therefore it also should be valued as a social or cultural document.

$H H T$ is related to events, part real and part imaginary, about the heroic deeds and exploits of a probably 14th or 15th century Malacca warrior hero, named Hang Tuah. In the epic he plays a two-faced role-as a king's servant (hamba) whose relentless loyalty helped upkeep the feudal order intact and also as the national hero whose heroic prowess both regionally and internationally was, according to Farish A. Noor (2010), helped defend the "Melayu" and the "negeri". This dual role of being a servant and a saviour, became the guiding principle of all his actions and decisions, which subsequently morphed him into the epic hero as he was visualized to be.

The epic apparently had as its nucleus, another great medieval textthe Sejarah Melayu (henceforth SM). It was here that Hang Tuah was first unfavourably mentioned. Contrary to the ideal image of him portrayed in the 
epic, here he appeared as an ordinary human, an ambitious courtier whose many failings helped highlight the Bendahara's noble character. To quote Josselin de Jong (1965:142):

The annals depict a man of very great qualities of valour and initiative, but also with human failings of ambition, spite and jealousy ... a normal ... human being, whose life was of the normal human span, and whose death was apparently quite unremarkable.

However, $H H T$, if we may correctly put it, was an offshoot of $S M$. The inter-textual link between the two is more than obvious (see T. Iskandar, 1970). Borrowing on Riffaterre's concept of intertextuality (in Teeuw, 1983), $S M$ is a "hypogram" for $H H T$, the text for it to plug in, but also to dismantle and sometimes inverted; thus, while parasitizing on the parent text, it also appropriates it to create its own.

$H H T$ was probably composed around early 18 th century (1688-1710), about 100 or more years after the completion of $S M$; and most probably written within the vicinity of the Johor-Malacca court, likely to be in Riau. It was composed (in writing) singlehandedly by an author (though anonymous) and not as many believe was a collaborative effort over time by several authors (Farish A. Noor, 2010). HHT is indeed a massive text but with such strong structural coherence and wholeness (single structure and meaning) that it was unimaginable to think of it being augmented at different times by different authors. To string together such heterogeneous materials as what was found in the $H H T$ and composing it into a single, meaningful, coherent and highly sophisticated text, will demand the skill of one, superbly creative, highly intelligent (the Malay word is arif bijaksana) and talented author. We believe the author of $H H T$ was such a person.

Authorial sources (oral and written) can be numerous, and indeed the author of $H H T$ do tap his materials from these informants, among these sources (traceable in the texts) include works form authors of Sejarah Melayu, Bustan al-Salatin, Taj al-Salatin, Hikayat Aceh, even Hikayat Ibrahim Ibn Adham (T. Iskandar, 1970; Braginsky, 1990 ). But we need one author to consciously select, manipulate, appropriate and arrange these diverse materials to bring forth singlehandedly a unique literary creation as monumental as HHT. In comparison, one may be allowed to take as an example the two great Indian canonical epics - Ramayana and Mahabharata. Both epics were built upon diverse and heterogeneous materials (local history, legends, tales etc.) but it took one single author-Valmiki and Vyasa respectively, to finally arrange and 
thread together the diverse materials to form the two magnificent, unparalleled Indian epics (Dandekar, 1956; Noriah Taslim, 1994).

An epic is a traditional story-it has its nucleus in the history and the tradition of its nation. The sources or the building blocks do not originate independently from the author's own experience or his own imaginations. It has to be based either on the collective memory and imagination of its people-stories of the past: memorats, anecdotes, myths and legends, or the recorded history. Apparently, the structural core of $H H T$ is based on the history of Malacca-its formation, expansion and fall as recorded in the book of the Malay Kerajaan $\operatorname{Order}^{2}$ that is, the $S M$.

We have mentioned earlier on, $S M$ is the proto-text for $H H T$, a hypogram of sorts-but they are hardly similar. However, this is not surprising, since both texts serve different purposes, prioritize different themes ${ }^{3}$ and subjected to different creative tendency; and of different genres. HHT is an epic. It abides by different genre convention than the $S M$, which is of course an annal/chronicle/silsilah. Epic brings forth themes of heroism, its plot coheres on heroic deeds and exploits; its creative tendency is to weave in and blend episodes, scenes, themes and motifs with the sole purpose of building a national and cultural hero. However, these are not the priority of an annal or silsilah, which gives preference to issues of state, statecraft and kingship.

Besides the raging storm over the controversy of Hang Tuah's identity, we still believe as the Malay folks in the past and in the present believe, (Muhammad, 2010-introduction to the epic) that he was an actual living person. ${ }^{4}$ We hold to the opinion that collective memory passed down through a chain of tradition bearers is as reliable as history, ${ }^{5}$ in the sense that in traditional society mind repeats mind, they do not create. Supomo (1979:183) quoted " ... this was done in accordance with the doctrine of the epic world which concerns itself with what should be rather than what it was...", leading us to concur that the larger parts of Hang Tuah's persona are greatly exaggerated and the events described are mostly imaginary or fictitious. In short, the so-named fictitious parts of the narratives are true and valid according to the author's vision and the inner logic of the epic world.

If we can rely on $S M$ as our point of factual reference, then we have to agree that Hang Tuah was indeed a real person, living in Malacca (serving at the court of Malacca, during the reign of Sultan Mansur Shah). Stories about him, probably his heroic prowess, must have existed and circulated orally during that time and probably also even after the fall of Malacca in 1511; these were augmented along the way and later coalesced into local 
legends. At certain point of time, these stories were further embellished to create what we now see as the epic hero Hang Tuah.

\section{THE EVOLUTION OF THE EPIC: READING THE PROCESS AND THE EPIC}

Indeed, in most epics of the world, the hero was an outgrowth of the nation's legendary heroes. To quote Shipley (1970:101):

The epic is an outgrowth of traditional story-telling; throughout its development heroes and deed have been chosen for celebration because of their fame among men. Invention is restricted to shift of stress, elaboration, variation of details. The poet's powers are devoted not to making a story, but to making an epic out of a famous story.

The above view stresses on the fact that epic was an outgrowth from the tradition of story-telling in the past. Its nucleus was the heroic legends and sagas-these were stories that recount and celebrate heroic deeds of famous folk heroes. Heroic sagas and legends were stories inspired by significant deeds of actual figure and events in the history of an ethnic group or clan. Legends about the figure sprouted as soon as stories about his deeds circulated within the community. According to Chadwick (in Felix J. Oinas, 1978:19):

... primary heroic stories are contemporary, i.e. the first stories that celebrate a hero's exploits are composed within living memory of the events ... we do not know any examples of heroic poetry or saga relating to recent events, in which the leading characters are fictitious.

The preceding views offer us with a better understanding of the literary phenomenon behind the making of $H H T$. Furthermore, it helped solidify the belief that Hang Tuah was a real person, a very respectable and admirable one among the Malay folks at the time; so much so that stories and legends celebrating his deeds and adventures soon began to circulate orally among the folks and form what Koster (1997) terms as the "Book of Tradition"- the book of the memory of the wise ancestors. In 18th century these memories were recalled, and became the stock reference for the author of $H H T$.

As we mentioned earlier, an epic is a traditional story in a sense that its materials came not from the author's own imagination or experience but from tradition-the so-called cultural models (Culler, 1975) or corpus of tradition. Facts, truth, logic in the modern sense were not the guiding principle in 
selecting these stories. Traditional literature worked on what Maier (1985) terms as "art of relevance"; stories, episodes, themes, motifs were absorbed into the hikayat for their relevance in conjuring up a convincing picture of the past, not for their validity or truth. In this respect history, legends, myths were treated equally-as traditional stories to be used or appropriated by the scribe in his creative endeavour to build a convincing story. As such history or "the past" to quote Errington (1979:39):

... did not have a special status within the genre hikayat...depleted of their historicity, they are absorbed by the hikayat into its own substance, for its own purpose.

The current discussion is relevant because it helped maintained the idea that in an epic hikayat like $H H T$, facts and fictions, history and legends are not contradictory to each other or are irreconcilable, but rather mutually dependent in creating a realistic picture of the past. This brings to mind another regional epic-the Hikayat Meukuta Alam, a 17th century epic from Aceh (Imran Teuku Abdullah, 1991). The text, following the literary convention of the time, weaved in episodes from local beliefs (folk history) and collective memory as well as history to bring forth the glorious picture of Aceh as the champion of Islam in the Straits of Malacca, during the reign of Iskandar Muda. Standing tall and invincible on the epic stage is of course the legendary figure Malem Dagang, a vague figure in Acehnese history and of an uncertain identity. To a person unaccustomed to Malay literary convention, the text would appear as an uncritical farrago of legends and tales; historical events when present were manipulated, turned upside down ${ }^{6}$ or omitted entirely to be replaced with legends and local beliefs (see Noriah Taslim, 2012). Similar to the author of $H H T$, what was vital to this author was not the historical accuracy but the truth according to the vision of its people.

Surely the main source of the hikayat material was not "the past" (meaning, history) but rather other hikayats, stories, tales and legends. Traditional texts repeat other texts; creativity is limited to variation in style, themes, plot, and other structural elements. Traditional authors (Koster, 1997) showed a strong commemorative tendency to copy, to mimic and to repeat other texts (especially canonical texts). In traditional society, where tradition stood for authority and truth, plagiarism was not a vice; repetition was a clever technique of securing acceptance (see Maier, 1985).

$H H T$ is no exception. Thus, for the author to create a convincing picture of the epic world, stories, legends, myths from folk tradition, fragment of 
stories from other hikayats-silsilah, epic, romance, adab became part and parcel of his narrative building blocks. However, as a point of caution, we must not be misled into thinking that these materials were simply, to put it in Errington's (1979:39) maxim: "caught ... by a scribe and given a name". The process of "borrowing" involved careful selection, skillful adaptation and conscious arrangement of materials in order for them to fit neatly into his grand design. The next part of the essay will try to focus on the process of "borrowing" and "selecting" materials from a pool of resources within the collective memory of the forefathers and the author's grasp.

First and foremost, the contents of $H H T$ as noted above, suggest obvious connections with $S M$, its predecessor and proto-text; many scholars (one of them, T. Iskandar, 1970) have enumerated in details the inter-textual links between the two. The main interest is not just to see the commonality between these texts, but rather to bring to attention the "process of critical borrowing" and the narrative strategy involved. Due to the limitation in space, I would like to focus only on several episodes in SM and HHT namely, the relationship with Keling, China, and Majapahit (Javanese).

Benua Keling (Vijayanagar) was the ancestral home of the Malacca forefathers, so it says in $S M$-it has a genetic link as well as political link with the Sultans of Malacca. In $H H T$, this genetic link was enhanced by the appointment of Sang Jaya Nantaka (the younger brother of Malacca Sultan) as the ruler of Benua Keling. Since these rulers were close relatives, Hang Tuah was despatched by the Sultan of Malacca as a "goodwill" ambassador to Benua Keling. ${ }^{7}$ The episode was relevant as it prepared Hang Tuah for another role-as a diplomat who established international rapport through diplomacy and negotiations. Furthermore, since the ruler was also the direct descendant of the Bukit Seguntang line; Hang Tuah was also obligated to serve him; thus, when he ordered Hang Tuah to visit China, Hang Tuah obediently and diplomatically took it upon himself to accomplish the task. ${ }^{8}$

This episode is critical to the author of HHT in a sense that it paved the way for Hang Tuah to enter the international arenas; he had to be standing tall not just in his home ground but elsewhere as well. Apart from that, the visit to China would allow Hang Tuah ${ }^{9}$ not only to be framed as an international figure, but also allowing him to belittle China, the Malacca arch-rival. By doing so, such action would help restore the dignity of the Malays (which had been tarnished in $S M$ ). This was done surprisingly, not through his craft as a warrior but through his clever negotiation as a diplomat. ${ }^{10}$ The author also used the theme of KelingChina-Malacca connection to show the other side of Hang Tuah. ${ }^{11}$ 
$S M$ had shown that the diplomatic ties between China and Malacca, existed in a rather ambiguous and awkward situation. While unable to overshadow China in term of greatness, Malacca attempted to accomplish this through the Sultan's daulat, and this proved successful; it managed to force China to mengirim sembah (literally to prostrate, as an act of acknowledging the sovereignty of Malacca) and not, as had been practiced, to mengirim salam (cordial greeting). The author of HHT used this episode, to deride China further and simultaneously extolled Hang Tuah as an exceptionally cunning Malay viz. a rakyat of the Sultan of Malacca. The event was very controversial, yet easily accomplished by Hang Tuah. While none could see the Chinese Emperor's face, Hang Tuah did so cunningly and instead of being punished (put to death) he was in fact praised by the Emperor. This was something to be reckoned with.

Another controversial episode in HHT is the Malacca-Majapahit viz. Melayu-Javanese connection. The love-hate relationship between the two kingdoms, the never-ending conflicts and struggle for supremacy between them, plays a significant role in $H H T$ and $S M$. However in $H H T$, the relationship was really put to test. Unlike $S M$ the Malacca-Majapahit connection became the central theme and the main preoccupation in the first half of the epic (the period of consolidation of Hang Tuah and Malacca); here the conflicts were not merely physical but problematized and refined to reach more or less a symbolic level. Reading it this way, the rivalry between the two powers, became the controlling metaphor in HHT. Episodes, personage (Hang Tuah and Patih Gajah Mada), weapon (the keris Taming Sari) and even the marriage between Sultan Mansur Shah and Raden Mas Ayu became signifiers, and need to be read as such.

One of the proponents of this metaphorical or allegorical reading of $H H T$ is Braginsky (1990). To him HHT is a "pasemon" a political allegory of the Johor-Jambi (read: Malay-Javanese) conflicts in 17th Century. Hang Tuah in real life was Laksamana Abdul Jamil, the hero in the history of the Johor-Jambi war; in the texts these were signified by the Malacca-Majapahit bitter conflicts. Braginsky agreed with his predecessor, Parnickle (1962) that believed it was this war that inspired the writing of HHT. According to them, the political allusions between text and history are too convincing to deny this symbolic affinity.

The symbolism inherent in the hikayat manifests itself not only in the main episodes, but also in several other scenes. To list a few: 
(a) The victory of a white mouse deer (pelanduk) over the powerful hunting dogs of the Javanese prince foretold the victory of Malacca over Majapahit in the future, which includes the victory of Hang Tuah over Taming Sari-the greatest of Majapahit warriors and over Patih Gajah Mada-the paladin of the Majapahit throne.

(b) Hang Tuah's victory over the warrior Taming Sari and the subsequent acquisition of the deadly keris Taming Sari, symbolizes the transference of Javanese invincibility as well as her good fortune (the Malay word is tuah) to Malacca.

(c) The appointment of Raden Bahar (Sultan Mansur Shah's son with his Majapahit consort) to Majapahit's throne signifies the taking over of Majapahit's political power and Javanese lineage to the throne by the Malays.

Other readings of a similar nature were also attempted by several other scholars such as Teeuw, (1964); T. Iskandar, (1970), Kamarudin A. Said (1992) and most recently, Farish A. Noor (2010). Rather, in retrospect, one may say that HHT is indeed a profound text; as a work of art, it is both transparent and opaque and opens itself to a double-sided reading. One may choose to read it literally or otherwise. The Majapahit episodes could be literally a satisfactory read. However, reading these as metaphors open them to a wider semantic field. The author had appropriated metaphors as an allusion to the actual events in the world, and more importantly as a literary technique and narrative strategy to discredit and deride Majapahit and the Javanese. Again, if we choose to read these episodes as metaphor, then history, chronology, accuracy of facts becomes irrelevant.

But why there was such a deep resentment against Majapahit? Antagonism and disrespect towards this Javanese kingdom had been shown as early as Hikayat Raja Pasai. ${ }^{12}$ However, no texts showed as much grudge to Majapahit as HHT. This was seen not only through the degradation (morally, physically, mentally) of the Javanese characters (as opposed to the excellent characters of the Malays) but also in the ironic ways episodes were treated. To mention a few:

a) The keris Taming Sari was presented by the Betara Majapahit to Hang Tuah who later used the keris to fight against him (including the killing of the seven Merga Sakti brothers).

b) Hang Tuah acquired the ultimate knowledge (the Malay term for this kind of knowledge is $i \operatorname{lmu}$ ) on the art of being a warrior (spiritually and 
physically) from the Javanese guru and ascetic Sang Persata Nala; it was these very skills that later helped Hang Tuah to defeat Majapahit (including killing Majapahit's strongest warrior-Taming Sari and all the other thousands of Javanese warriors)

c) Sang Persata Nala-the most reputable and distinguish guru on the island of Java then, was shown to favour the Malays (Hang Tuah and his four comrades) over his very own people.

To answer why there was such a deep resentment against Majapahit, one needs to delve deeper into the past and see how history, collective memory and tradition intertwined and blend to paint the unattractive picture of Majapahit, which unfortunately left a deep imprint in the collective unconscious of the Malays.

As early as 7th century the Malay ancestors were the proud owner of a glorious past, marked by a prosperous kingdom and a huge empire, called Sriwijaya, located in the Palembang-Jambi area. This Sumatra-based (Malayu) kingdom was able to sustain its suzerainty over a vast area in the region for a long time and able to balance the Javanese power in Majapahit (Supomo, 1979). However in the late 14th century, history told us that Jambi-Palembang was destroyed by the Javanese, ${ }^{13}$ its ruler (Parameswara) was banished and forced to flee and after years of trying to a get a settlement, finally found Malacca. Sriwijaya then became the vassal of Majapahit-the most powerful empire in the archipelago (Supomo, 1979). The fall of Sriwijaya had also dragged down the glorious ancient Malay civilization that lasted for more than 500 years. Thus, the Malays had every reason to resent the Majapahit.

To add salt to the wound, tradition-hikayats, legends had shown various incidences of clashes and conflicts with Majapahit. Stories were told that it was Majapahit that ravaged and looted Pasai in Hikayat Raja Pasai ${ }^{14}$ and forced the Sultan to escape in a wretched state, journeying for about fifteen days to Menduga. Then it was Majapahit too that besieged Singapura in $S M$ and forced Iskandar Shah, (raja Melayu yang berasal dan berusul) the descendent of the auspicious Seguntang line, to vacate the palace, fled to Muar and later with a handful of supporters founded Malacca. The stories of ancestral defeats at the hands of Majapahit were humiliating to the Malays; these stories came down to the author of HHT as bitter memories of the Malay's past.

Apparently, Majapahit was the arch-enemy of the Malays since days of yore. It was only proper that the Malay saviour cum hero, Hang Tuah, should stride forth and save the Malay's maruah (honour, respect) by degrading and 
crushing the Javanese people or warriors, the Betara of Majapahit himself and Patih Gajah Mada (the ruler's most trustworthy minister). By doing so, he resolved the age-long predicaments of the Malays. Although the conflicts were only resolved in fiction, but poetic justice prevailed; the villain was punished and psychologically the Malays won the battle.

More recently, (in 17th Century) the Malays in Johor had to suffer aggressions from the South Sumatran principality of Jambi, which according to Braginsky stood for Majapahit (1990:400):

since the rulers and aristocrats of this principality bore Javanese names and titles and the principality itself was a vassal of the Javanese state of Mataram.

If Jambi stood for Majapahit, then the age-long animosity between Majapahit and the Malays was rekindled and brought to the fore; although the war ended with Johor's victory, but the "evil" had returned into the Malay life. This was reason enough for the author of $H H T^{15}$ as noted by Parnickel (1962:150) to strive "to project the present into the past."

\section{THE RISE OF HANG TUAH-READING THE MILIEU AND TIME}

We now come to the next part of the essay; what inspires an author to hoist up an ordinary courtier or warrior in $S M$ to become a supra-human or what Josseline de Jong (1965:140) described as "the ideal man, warrior, and citizen ... a tutelary genius of the Malay people" in HHT? In reply, one needs to look really close at the socio-political scenes and the psychological setup behind the making of this epic hero.

I like to begin with the premise that a hero is not born but made. This brings to mind the theory of the "rise and decline of a national hero" by Josselin de Jong (1965). In his article, he posits that the rise (in 17th century) and decline (in 20th century) of Hang Tuah in Malay society were linked to the socio-political as well as ideological state of the Malays at the time, which influenced the values attached to this hero. However, I do not wish to elaborate the processes traced by Josselin de Jong in the essay; suffice to say that he had given a very convincing picture of the factors that helped elevate Hang Tuah to his mythical status, as well as factors that brought his downfall.

Applying his theory, but working slightly on different terms, I would now attempt to look at the scene behind the making of the epic hero. I suggest we should once again look at socio-political predicaments of the Malays in the 17 th and 18 th century, the period $H H T$ was believed to be composed. The 
above centuries and probably earlier, was a dark and turbulent period for the Malays. It witnessed one of the worst degradation of Malay power politically and economically, in the hands of both foreign and locally emerging power. Ever since 1511, the Malacca-Johor kingdom had been beset unceasingly by a number of calamities-the prolonged attacks from Portuguese (1518-1536, Andaya, 1978) followed by Aceh (1613-1682, Andaya, 1978) and Jambi (1650-1680, Braginsky, 1990).

After the fall of Malacca, the Malay kerajaan (kingdom) had lost its status as an overlord to the maritime states along the Selat Melaka (Strait of Malacca), subsequently losing its trade control in the area. Without the political and economic power, it is difficult to retain the support of the orang laut which had been the main thrust in Malacca's naval power. Without these, the Malay kerajaan became very vulnerable. The Malacca Sultan's early attempt to reconstitute his kerajaan in Johor was barely successful and his power was virtually defunct. The Malacca-Johor ruling house had to be continually shifted to keep its stability. To make matters worse, the JohorMalacca kingdom was continually bombarded and besieged.

The internal strife and political instability, the continuous threat and harassment from outside had brought the Malay society into an acute state of chaos and anarchy as never witnessed before. All over the world, such adverse social situation will induce the growth of a strong ethnocentric fervour, a heightened sense of ethnic solidarity. Within this strong ethnocentric consciousness, the ethnie tends to revere figures who strive to defend the territory and the sovereignty of the group (Smith, 1972; Noriah Taslim, 1997). This age of hero-worship was designated as the heroic age-the age dominated by heroes. It was this ethnocentric fervour that inspired the creation of heroes; and subsequently historical figures, legendary heroes were embellished with superhuman attributes and elevated to an epic hero.

Hang Tuah was such a figure. He re-emerged from $S M$ and got re-figured by legends and tales, (as speculated by Braginsky, 1990; T. Iskandar, 1970) in the midst of this socio-political instability and upheaval, heightened and made more critical probably by the Johor-Jambi wars in 17th century. The stage was indeed set for the entrance of the hero. In T. Iskandar's words (1970:45)

$H H T$ was created to boost the morale of the Malays to regain their greatness, such as that during the Malacca period.

Therefore, Hang Tuah emerged on the scene and was given a superhero status and all the attributes therein. He was, so to speak, "the man on the 
spot", brought forth by the milieu and time and created to be the ultimate saviour of the Malays and their rajas. In the epic, the maruah (honour, respect, dignity) of the Malays, the survival of the kerajaan and the rulers were interlinked with Hang Tuah. Until to this day, he has been portrayed as champion of the Malay course, symbol of the Malay spirit (semangat) and political survival (see Farish A. Noor, 2010). Held by the Malays as their "spirit guardian", we were told that at end of the hikayat, Hang Tuah did not die but mysteriously disappeared, suggesting the possibility that he would reappear when the Malays were once again threatened. This belief lingers on until today (see Josselin de Jong, 1965); there are even stories from people who claimed that they had seen Hang Tuah (or apparition of him) especially in the vicinity of Gunung Ledang (see Muhammad Haji Salleh, 2010). Thus, his legends go on.

Hang Tuah then became a common depository of the collective wishes and aspiration of the Malay community, living in an age of instability and impoverishment of Malay power. Apparently, the Malays for a long time had been exposed to heroes who fought gallantly to defend the aspirations and ideals of their communities. From the Indic traditions, came the larger than life heroes such as the Pandawa brothers, Rama, Hanuman and Laksamana; while from the Arab Muslim world, they witnessed the mighty deeds of Islamic heroes-Amir Hamzah and Muhammad Hanafiyyah. These encounters ignited the Malay's desire to have their own hero who could fit into the universal mould yet fought for the Malay's aspiration.

Since days of yonder, the Malays (like most pre-modern societies) had placed high esteem on warriors or fighters who had shown great skills in combat and battle. Living as it was in a world of constant strife for sustenance and frequent clashes among various ethnic groups, heroic quality is a necessity and heroism is an admirable attribute. Within such hostile environment, survival, victory and empowerment would depend almost solely on physical strength and competency. Such circumstances would favour physical engagement in solving conflicts as well as other life's predicaments. Thus physical combats and in its more complex form, battle, became a common phenomenon and in fact cherished by the traditional community. The manifestation of this passion for heroic endeavours, physical actions (sometimes violently) and battles scenes (most times bloody and gruesome) could be discerned in various literary genres-court romance and epic were the champions. 


\section{CONCLUSION}

As a conclusion I would like to draw the opinion of W.J. Ong (1982) whose research on the the so-called psychodynamic of orality in traditional society, helped explain what he termed as the agonistic and antagonistic tendency among pre-modern, pre-literate society. According to him (1982:43), traditional society "was extraordinarily agonistic in their verbal performance and indeed life styles...."

Furthermore, according to him, early society existed in a context of struggle and competition not only verbally but physically. This agonistic behaviour is manifested in their verbal arts. To quote him again (1982:44) "The common and persistent physical hardships of life in many early societies of course explain the high evidence of violence in early verbal arts...."

Living in such closed-knit oral society had its advantages and disadvantages; although seemingly cordial, members of traditional societies were also inherently antagonistic. According to Ong, (1982:45):

Violence in art forms is also connected with the structure of orality itself. When all verbal communication must be in direct word of mouth ... interpersonal relations are kept high-both attractions and even more, antagonisms.

Finally, one can surmise that $H H T$ was the product of such time and worldview-an age where passions for combats and battles and heroic exploits were excessive. In him, the Malays, also found qualities needed for their survival. Thus, besides being an icon to his community, Hang Tuah fulfilled the psychological needs of the Malays; he stood for them, during their bleak and trouble time. They believed that he would still be there in the future if ever the Malays again needed him.

Finally, by looking at the scenes-literary, social, political and psychological, behind the composition of $H H T$, one can understand the reasons why such an epic scale of Hang Tuah was called for. Indeed, it was not an exaggeration to say again that an epic hero is built and not born.

\section{NOTES}

1 See Braginsky, 1990; T. Iskandar, 1970, for review of these comments.

2 The concept is taken from Koster (1997), it refers to canonical texts which lay down rule for good governance; these texts were also called "adab" texts or book of Mirrors for Princes.

3 Although both Hikayat Hang Tuah and Sejarah Melayu deal with the fundamental 


\section{MALAY LITERATURE}

theme of the relationship between ruler and subjects (hamba)

4 c/f the recent finding by John Miksic, 2012 which offers hard proof of Hang Tuah's existence.

5 If not more reliable; on the reliability/factity of history read White, 1978; Kramer, 1989; La Capra, 1983.

6 For example, the Acehnese war against the Portuguese in Malacca.

7 In Sejarah Melayu, the role was given to Hang Nadim (the son of Hang Jebat); the task, however was not diplomatic but trade.

8 Without stopping on the way to ask permission from the Sultan of Malacca

9 In Sejarah Melayu the task was accomplished by Tun Perpatih Putih, one of Malacca's court dignitaries.

10 Refer to the famous episode of eating Malay spinach (sayur kangkung) in Hikayat Hang Tuah.

11 For the other side of Hang Tuah, especially his character as a diplomat, see Farish A. Noor, 2012.

12 For the image of Majapahit in Hikayat Raja Pasai, read the episode on the the bull fight in Pulau Percha and the legend of Minangkabau.

13 Apparently Jambi and Palembang were besieged by Mataram and Majapahit, see Supomo, 1979.

14 Of which the texts says, "so that every boat was loaded with such quantities of booty and prisoners that it was filled to overflowing."

15 Written according to Braginsky (1990), soon after the Jambi War.

\section{REFERENCES}

Andaya, Leonard. Y., 1978. The Kingdom of Johor 1641-1728. Kuala Lumpur: OUP.

Bynan, David, E., 1976. "The Generic Nature of Oral Epic Poetry" in Dan Ben Amos(ed.), Folklore Genres. London: University of Texas Press. Braginsky, V.I., 1990. "Hikayat Hang Tuah, Malay Epic and Muslim Mirror, some Considerations on its Date, Meaning and Structure" in BTLV 146.

Culler, Jonathan, 1975. Structuralist Poetics: Structuralism Lingusitics and the Study of Literature. London: Routledge and Kegan Paul.

Dandekar, R.N., 1956."Indian Literature" in Encyplopedia of Literature. New York.

Errington, Shelly, 1979. "Some Comments on Style in the Meanings of the Past" in A. Reid \& D. Marr (eds.), Perception of the Past in Southeast Asia. Hong Kong Singapore: Heinemann.

Farish A. Noor, 2001. "Deconstructing Our National Hero" in Farish A. Noor, What Your Teacher Didn't Tell You. The Annexe Lectures. Vol. 1, Petaling Jaya: Matahari Books. 
Hooykass, C., 1953. Perintis Sastera. Groningen/Jakarta: Wolters.

Josselein de Jong, P.E., "The Rise and Decline of a National Hero" in JMBRAS 38 Pt II, 1965.

Kamaruddin A. Said, "The Signifier and Heroes in the Hikayat Hang Tuah: a Reinterpretation" in Malay Literature 5:2, 1992.

Imran Teuku Abdullah, 1991. Hikayat Meukuta Alam. Jakarta: Penerbit PT Intermasa.

Iskandar, T., "Some Historical Sources Used by the Author of Hikayat Hang Tuah" in JMBRAS 42, Pt II, 1970.

Kassim Ahmad, 1964. Characterisation in "Hikayat Hang Tuah". Kuala Lumpur: Dewan Bahasa dan Pustaka.

Koster, G.L., 1997. Roaming Through Seductive Gardens. Leiden: KLTV Press.

Lerner, Lawrence, 1990. "History and Fiction" in Dennis Walder (ed.), Literature in the Modern World. Oxford: Oxford University Press.

Maier, H.M.J., 1985. Fragments of Reading: The Hikayat Merong Mahawangsa. Albasserdam: Kanters.

Miksic, John, 2012. "Dunia Melayu dan Singapura: Dari sudut Arkeologi”. Paper presented at the National Museum Singapore organized by Taman Warisan Melayu, 30 April, web page:http://cyberita.asia1.sg/ msingapura, access on 1/5/2012.

Muhammad Hj Salleh, 1999. "Mendialog Wira: Hujah di Sebalik Kata" in Muhammad Hj Salleh (ed.), Menyeberang Sejarah. K. Lumpur: DBP. The Epic Hang Tuah, 2010. Translated by Muhammad Hj Salleh. 2010. Kuala Lumpur: ITNM.

Noriah Taslim. "Genre Epik: Antara Kesukuan dan Kesejagatan" in Dewan Sastera, September, 1994.

Noriah Taslim, 1997. "To Vindicate a Claim to Greatness: Political Nationalism and the Writing of the Malay Annals" in National Build-up and Literary/Cultural Process in Southeast Asia. Moscow: Institute of Asian and African Studies.

Noriah Taslim, 2012. "Wira, Sejarah dan Sentimen Etnosentrisme dalam Hikayat Meukuta Alam". Kertas utama untuk Seminar Antarabangsa ADIC 2012, Universiti Islam Antrabangsa, Gombak, 26-28 Mac.

Oinas, Felix, J. (ed.), 1978. Heroic Epic and Saga. Bloomington: Indiana University Press.

Ong, W.J., 1982. Orality and Literacy.The Technologizing of the Words. London, New York: Methuen. 
Parnickel, B.B., "An Epic Hero and an Epic Traitor in the Hikayat Hang Tuah" dlm. BKI 132, 1976.

Said, Edward, 1979. Orientalism. New York: Vintage Books.

Shipley, Joseph, T., 1970. Dictionary of World Literary Terms. London: George Allen \& Unwinch.

Smith, Anthony. D., "Ethnocentrism, Nationalism and Social Change" in International Journal of Comparative Society, XIII, 1972.

Supomo, S., 1979. "Image of Majapahit in Later Javanese and Indonesian Writing" in A. Reid and D. Marr (eds.), in Perceptions of the Past in Southeast Asia. Hong Kong, Singapore: Heinemann.

Teeuw, A. "Tentang Penghargaan dan Pentafsiran Hikayat Hang Tuah" in Dewan Bahasa, 8, 1964.

Teeuw, A., 1983. Membaca dan Menilai Sastera. K. Lumpur: DBP.

White, Hayden, 1978. Tropics of Discourse: Essays in Cultural Criticism. Baltimore: John Hopkins University.

Winstedt, R.O., 1961. A History of Classical Malay Literature. K. Lumpur: OUP. 